\title{
Başeditörden
}

\section{Tolga AKSU}

Sağlık Bilimleri Üniversitesi, Derince Eğitim ve Araştırma Hastanesi, Kardiyoloji Kliniği, Kocaeli, Türkiye

Değerli Meslektaşlarım,

Türkiye'nin genel tıp bilimleri alanında, önde gelen bilimsel dergilerinden birisi olma hedefini ilk kurulduğu günden günümüze kadar sürdüren Kocaeli Tıp Dergisi'nin Baş-editörlüğü görevini Ocak 2018'den itibaren üstlenmiş bulunmaktayım. Bugüne kadar bu değerli görevi üstün fedakarlıklarla ve layıkıyla yürütmüş sayın Doç. Dr. Erkan Şengül ve Sayın Doç. Dr. Kemal Tolga Saraçoğlu gibi iki değerli akademisyenden bayrağ 1 taşıma görevini şahsıma vermiş dergi imtiyaz sahibimiz ve Sağlık Bilimleri Üniversitesi, Kocaeli Derince Eğitim ve Araştırma Hastanesi yöneticisi Doç. Dr. Hüseyin Şaşkın'a, dergimizin kurucusu Prof. Dr. Zekeriya İlçe' ye ve bugüne kadar editör kurulunda yer almış ve halen aktif olarak çalışmakta olan tüm hekim arkadaşlarıma teşekkür ediyorum. Çalışmaya başladığım ilk andan itibaren, bölüm editörlerimiz dergiye ne denli önem verdiklerini ve alınacak yenilikçi kararların arkasında ve destekçisi olduklarını gösterdiler. $\mathrm{Bu}$ destekleri için kendilerine ayrıca teşekkür ederim.

Yeni dönemde eski dergi editörlerimiz sayın Doç. Dr. Erkan Şengül ve sayın Doç. Dr. Kemal Tolga Saraçoğlu ile editör olarak birlikte çalışmaya devam edeceğiz. Birlikte daha doğru ve etkili kararlar aldığımız bu iki arkadaşıma, önümüzdeki zorlu süreçte beni yalnız bırakmadıkları için çok teşekkür ediyorum. Dergimizin kalitesinin yükseltilmesinde büyük emekleri olan eski yazı işleri sorumlumuz Uz. Dr. Ayşegül Taş' in yeni dönemde danışman editör olarak farklı şekillerde yanımızda olacaklarından eminim. Yeni dönemde kendisinin görevi kıymetli meslektaşım Uz. Dr. Serdar Bozyel tarafindan yürütülecektir.

Baş editör olarak öncelikli hedefim, ulusal endekslerde taranan dergimizin önemli uluslararası endeksler tarafından da taranmasını sağlamak olacaktır. $\mathrm{Bu}$ amaçla yayın kurulunda köklü değişiklikler gerçekleştirdik ve sağlık bilimlerinin neredeyse tüm ana dallarında seçkin bölüm editörleri ile işbirliği yapmaya başladık. Ayrıca dergimiz sayfasını da bilimsel kriterlere uyumlu olacak şekilde revize ettik.

Yeni yayın döneminde değerlendirme sürelerinin hızlandırılmasına ve değerlendirme sonucu olumsuz olan yazarlara bile yapılacak hakem yorumları ile katkıda bulunmaya azami özen göstereceğim. Bu süreçte atanacak hakem arkadaşlarımızın da dergimizden desteklerini esirgemeyeceklerine, ayrıca yazarların kaliteli araştırmalarını bizlerle paylaşmaya devam edeceğine inanıyorum.

Dergimiz şu an itibari ile TÜBİTAK ULAKBİM TR, Türkiye Atıf Dizini tarafindan taranmakta olup kabul edilen tüm yazılara en kısa sürede DOI numarası atanmaktadır. Dahası önümüzdeki süreçte uluslararası endekslerce de taranması için gerekli başvurular yapılmıştır ve yapılmaya da devam edilecektir. Üniversiteler Arası Kurul tarafından belirlenen yeni Doçentlik kriterlerinde "ULAKBIM" tarafından taranan ulusal hakemli dergilerde yayımlanmış makalelerden en az 8 puan alınması gerekliliği Ulusal dergilerimizin bilim kalitesini yükseltmek bakımından önem taşımaktadır. $\mathrm{Bu}$ minvalde, dergimizin yazı dili Türkçe ve İngilizce olarak devam edecektir. Ancak yazarların yazılarının uluslararası değerini ve okunurluğunu arttırmak adına İngilizce yazıların teşvik edileceğini bilmenizi isterim.

Hep birlikte göstereceğimiz özveri ile dergimizin ulusal ve uluslararası görünürlüğünü arttırmak dileği ile,

Saygilarımla.

Doç. Dr. Tolga Aksu

Başeditör 